Proc. Indian Acad. Sci. (Earth Planet. Sci.), Vol. 95, No. 3, November 1986, pp. 381-395.

(C) Printed in India.

\title{
On the thermal and redox history of the Yamato diogenite Y-74013
}

\author{
AMALBIKASH MUKHERJEE and T A VISWANATH \\ Department of Geology and Geophysics, Indian Institute of Technology, \\ Kharagpur 721 302, India \\ MS received 12 August 1985; revised 10 March 1986
}

\begin{abstract}
The Yamato diogenite, Y-74013, shows a high degree of textural equilibrium with the apparent crystallization sequence: troilite and metal $\rightarrow$ orthopyroxene $\rightarrow$ plagioclase. The position of the large chromite crystals in this sequence is unclear. Except chromite, all other minerals have composition similar to common orthopyroxene achondrites. The chromite is more magnesian than in common diogenites, strongly zoned and, oil the whole, intermediate in composition between chromites of diogenites and pallasites. Texture, mineral composition data and an equilibrium thermodynamic analysis of the mineral association strongly indicate that the chromite crystallized earlier than the silicates at a much higher temperature (possibly above $1100^{\circ} \mathrm{C}$ ) and rapidly grew in a medium which was progressively enriched in $\mathrm{Mg}, \mathrm{Al}$ and $\mathrm{Ti}$. But the chromite failed to reach chemical equilibrium, even at its outermost rim, with the orthopyroxene. The calculated equilibrium $\log \mathrm{fO}_{2}$ of the Yamato diogenite, -20.21 to -11.08 for temperatures between $880^{\circ} \mathrm{C}$ and $1500^{\circ} \mathrm{C}$ is well within the normal oxygen fugacity range of pyroxene achondrites.
\end{abstract}

Keywords. Thermal history; redox history; diogenite; Yamato Y-74013 meteorite.

\section{Introduction}

Recent work on the Antarctic achondrites has thrown considerable light on the genetic relationships among certain achondrite groups, e.g. eucrites, howardites and diogenites. For instance, Takeda and Yanai (1982) have shown that the eucrite, howardite and diogenite clasts of the polymict Yamato-79 achondrites can be satisfactorily explained by impact processes on a layered parent body, in which the layer-sequence from the surface downwards may be: (1) surface-type, unequilibrated eucrite with Fe-Mg-zoned pyroxene, (2) shallow level, cumulate. eucrites, with inverted pigeonite and pyroxenes showing exsolution lamellae, (3) polymict eucrite with minor diogenite at intermediate depths, (4) howardites at the deep levels and (5) diogenites at the deepest level. One of the critical tests for such models would be quantitative thermometry and barometry of the different layers to find a reasonable and internally consistent $\mathrm{P}-\mathrm{T}-\mathrm{fO}$, profile across the layered parent planet. Possibly the most difficult object for such a test would be the diogenites, the nearly monomineralic orthopyroxene-rocks, to which the commonly available mineralogical P-T-sensors cannot be applied. The diogenites nevertheless play a key role in the evolution of the layered parent body and a quantitative estimate of the pressure and temperature of their equilibration — in conformity with their supposed location at the deepest level - is obviously of great interest.

In this paper, we present detailed petrology and mineralogy of the Yamato-74013 diogenite along with new electronprobe microanalyzer data bearing on its thermal and redox history. We also present new thermodynamic methods for quantitative 
estimation of the pressure and temperature of formation of essentially orthopyroxene-chromite meteorites and apply these methods to the Yamato diogenite.

\section{Petrography}

A medium-grained orthopyroxenite, Yamato Y-74013, shows xenomorphic orthopyroxene grains interlocked with frequently developed near $-120^{\circ}$ trijunctions (figure 1a). The orthopyroxene is colourless, non-pleochroic and optically negative with a fairly large optic axial angle. Cleavage traces are only feebly developed and extinction is straight in prismatic section. While some orthopyroxene grains are clear and nearly free from inclusions, many are densely charged with tiny opaque inclusions of troilite and metal (figure 1b). Anhedral to subhedral troilite has profusely grown as single grains or as composite grains with the metal phase. Somewhat larger subhedral troilite and metal grains also cluster at the orthopyroxene grain interfaces. The plagioclase occurs in the form of anhedral, clear pool interstitial to the orthopyroxene (figure 1c). The large chromite euhedra appear to be somewhat isolated from the silicate matrix. No clasts were observed. No evidence of brecciation or shock is also evident, except a moderate degree of fracturing affecting the orthopyroxene. The sequence of crystallization might be metal and troilite first, followed by orthopyroxene with a slight overlapping, and plagioclase crystallizing last. The typically 'interprecipitate' appearance of the plagioclase suggests accumulation (gravitative ?) of orthopyroxene crystals packed with early metal and troilite inclusions in a small amount of late, residual, interprecipitate liquid from which the plagioclase crystallized. The position of chromite in this sequence is unclear. On the whole, the texture indicates a high degree of equilibration and grain growth.

\section{Mineral composition data}

Composition data (tables 1-4) of orthopyroxene, chromite, troilite, metal and plagioclase were obtained from one polished thin section of Yamato Y-74013 diogenite prepared at the National Institute of Polar Research, Japan. The analyses were carried out with the JEOL JXA-35 electronprobe microanalyzer employing a 4-crystal wavelength dispersive spectrometer. Accelerating voltage, specimen current and beam diameter were $15 \mathrm{kv}$, between $0.20 \times 10^{-7}$ and $0.75 \times 10^{-7}$ amp and about $5 \mu \mathrm{m}$ respectively. All data were corrected for deadtime and background. The final microprobe data reduction was carried out using Bence-Albee method (Bence and Albee 1968) for the silicates and the oxides and the ZAF-based delta method of Hirata and Okumura (1976) for troilite and metal.

The Yamato orthopyroxene (table 1) is on the whole homogeneous and similar in $\mathrm{Fe} / \mathrm{Mg}$ ratio, $\mathrm{Al}, \mathrm{Cr}$ and $\mathrm{Ca}$ content to the common orthopyroxenes from diogenites. The Johnstown orthopyroxene is a little more magnesian. The Yamato plagioclase (table 4) is also quite similar to the Johnstown plagioclase. The higher An content of the plagioclase rim of the Yamato sample $(86.4 \%$ An for rim against $81.8 \%$ An for core) is indicative of a reheating event. But since only one plagioclase grain could be analyzed in the thin section, this observation has to be 


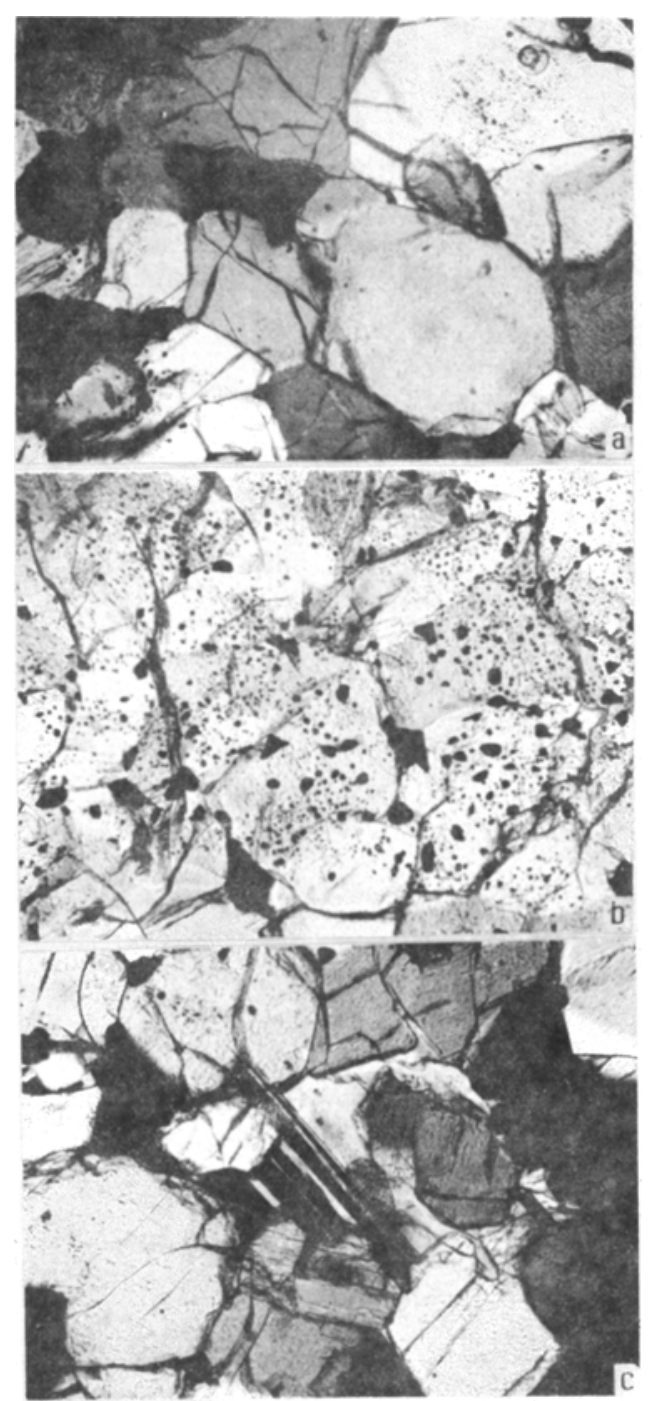

Figure 1. Photomicrograph of Yamato Y-74013 diogenite $(\times 40)$ a. Coarse, xenomorphic orthopyroxene grains forming near- $120^{\circ}$ trijunctions. Polars crossed. b. Coarse, xenomorphic orthopyroxene grains densely charged with opaque inclusions of troilite and metal. Single polar. c. Clear, anhedral pool of polysynthetically twinned plagioclase interstitial to orthopyroxene. Polars crossed.

confirmed by more data. The Yamato troilite (table 3), like common meteoritic troilite, is nearly stoichiometric with the structural formula $\mathrm{Fe}_{\left(1 \cdot \omega_{9}\right)} \mathrm{Co}_{(0) \cdot(\kappa) 1} \mathrm{~S}$. The metal phase (table 3 ) is nearly pure Fe with small amounts of $\mathrm{Co}$ and Ni. Our composition data on the whole agree with the previous reports (Takeda et al 1978). Comparison with several well-known diogenites (table 3 ) brings out the close similarity, especially with Tatahouine diogenite. We did not detect any significant grain-to-grain or within-grain variation in composition of the Yamato metal phase. The Yamato chromite (tables 2 and 5), however, shows significant compositional differences from the common orthopyroxene achondrites. It is considerably more 
Table 1. Orthopyroxene analyses.

\begin{tabular}{|c|c|c|c|}
\hline & \multicolumn{2}{|c|}{$\begin{array}{c}\text { Yamato } \\
\text { Y-74013 diogenite } \\
\text { Orthopyroxene }\end{array}$} & \multirow{2}{*}{$\begin{array}{c}\text { Johnstown } \\
\text { diogenite } \\
\text { Orthopyroxene }\end{array}$} \\
\hline & Rim & Core & \\
\hline $\mathrm{SiO}_{2}$ & 52.97 & $53 \cdot 30$ & $54 \cdot 10$ \\
\hline $\mathrm{Al}_{2} \mathrm{O}_{3}$ & $1 \cdot 66$ & $1 \cdot 51$ & $1 \cdot 06$ \\
\hline $\mathrm{TiO}_{2}$ & $0 \cdot 15$ & $0 \cdot 16$ & $0 \cdot 13$ \\
\hline $\mathrm{Cr}_{2} \mathrm{O}_{3}$ & 0.79 & 0.86 & $0 \cdot 81$ \\
\hline $\mathrm{FeO}^{*}$ & $17 \cdot 37$ & $17 \cdot 38$ & $15 \cdot 60$ \\
\hline $\mathrm{MnO}$ & 0.53 & 0.59 & 0.48 \\
\hline $\mathrm{MgO}$ & $25 \cdot 84$ & $25 \cdot 46$ & $26 \cdot 70$ \\
\hline \multirow[t]{3}{*}{$\mathrm{CaO}$} & 1.74 & $1 \cdot 65$ & $1 \cdot 28$ \\
\hline & $101 \cdot 05$ & $100 \cdot 91$ & $100 \cdot 16$ \\
\hline & \multicolumn{3}{|c|}{ Cations on the basis of 6 oxygens } \\
\hline $\mathrm{Si}$ & 1.92 & 1.94 & 1.96 \\
\hline $\mathrm{Al}^{\mathrm{IV}}$ & 0.06 & $0 \cdot 06$ & 0.04 \\
\hline $\mathrm{Al}^{\mathrm{VI}}$ & 0.01 & $0 \cdot 01$ & $0 \cdot 01$ \\
\hline $\mathrm{Ti}$ & 0.004 & $0 \cdot 004$ & 0.004 \\
\hline $\mathrm{Cr}$ & 0.02 & 0.03 & $0 \cdot 02$ \\
\hline $\mathrm{Fe}$ & 0.53 & 0.53 & 0.47 \\
\hline Mn & 0.02 & $0 \cdot 02$ & 0.01 \\
\hline $\mathrm{Mg}$ & $1 \cdot 40$ & $1 \cdot 38$ & $1 \cdot 44$ \\
\hline $\mathrm{Ca}$ & 0.07 & $0 \cdot 06$ & 0.05 \\
\hline Total & $4 \cdot 03$ & $4 \cdot 03$ & $4 \cdot 00$ \\
\hline Wo & $3 \cdot 5$ & $3 \cdot 0$ & $2 \cdot 5$ \\
\hline En & $70 \cdot 0$ & $70 \cdot 0$ & $73 \cdot 5$ \\
\hline Fs & $26 \cdot 5$ & $27 \cdot 0$ & $24 \cdot 0$ \\
\hline$X_{M g, M 1}$ & 0.72 & 0.69 & 0.73 \\
\hline $\mathrm{X}_{\mathrm{Mg}, \mathrm{M} 2}$ & 0.68 & 0.69 & $0 \cdot 71$ \\
\hline $\mathrm{X}_{\mathrm{Fe}, \mathrm{M} 1}$ & 0.27 & $0 \cdot 26$ & $0 \cdot 24$ \\
\hline $\mathrm{X}_{\mathrm{Fe}, \mathrm{M} 2}$ & 0.26 & $0 \cdot 27$ & $0 \cdot 23$ \\
\hline $\mathrm{X}_{\mathrm{MgAl}_{2} \mathrm{SiO}_{6}}$ & 0.0008 & $0 \cdot 0008$ & $0 \cdot 0006$ \\
\hline
\end{tabular}

* Total $\mathrm{Fe}$ as $\mathrm{FeO}$

** Average of 12 analyses (Floran et al 1981).

magnesian, its $\mathrm{Mg} / \mathrm{Fe}^{2+}$ ratio being almost midway between the corresponding diogenite and pallasite values. Table 5 displays the $\mathrm{Mg} / \mathrm{Fe}^{2+}, \mathrm{Y}_{\mathrm{Cr}}^{\mathrm{SP}}$ (i.e. $\mathrm{Cr} /$ $\left.\left(\mathrm{Cr}+\mathrm{Al}+\mathrm{Fe}^{3+}\right)\right), \quad \mathrm{Y}_{\mathrm{Al}}^{\mathrm{Sp}}\left(\right.$ i.e. $\left.\mathrm{Al} /\left(\mathrm{Cr}+\mathrm{Al}+\mathrm{Fe}^{3+}\right)\right)$ and $\mathrm{Y}_{\mathrm{Fe}^{3+}}^{\mathrm{Sp}}\left(\right.$ i.e. $\mathrm{Fe}^{3+} /$ $\left.\left(\mathrm{Cr}+\mathrm{Al}+\mathrm{Fe}^{3+}\right)\right)$ values of the chromites of Yamato diogenite, Johnstown diogenite (Floran et al 1981), type bronzite achondrite (Bunch and Keil 1971), and pallasite (Bunch and Keil 1971). The core $Y_{\mathrm{Cr}_{\mathrm{P}}}^{\mathrm{S}_{\mathrm{P}}}$ and $\mathrm{Y}_{\mathrm{Al}}^{\mathrm{SP}}$ values of the Yamato chromite are also midway between corresponding typical diogenite and pallasite values. This 'pallasitic' trend in the Yamato chromite composition suggests that the large chromite euhedra (especially their core sectors) did not grow in equilibrium with the orthopyroxene. 


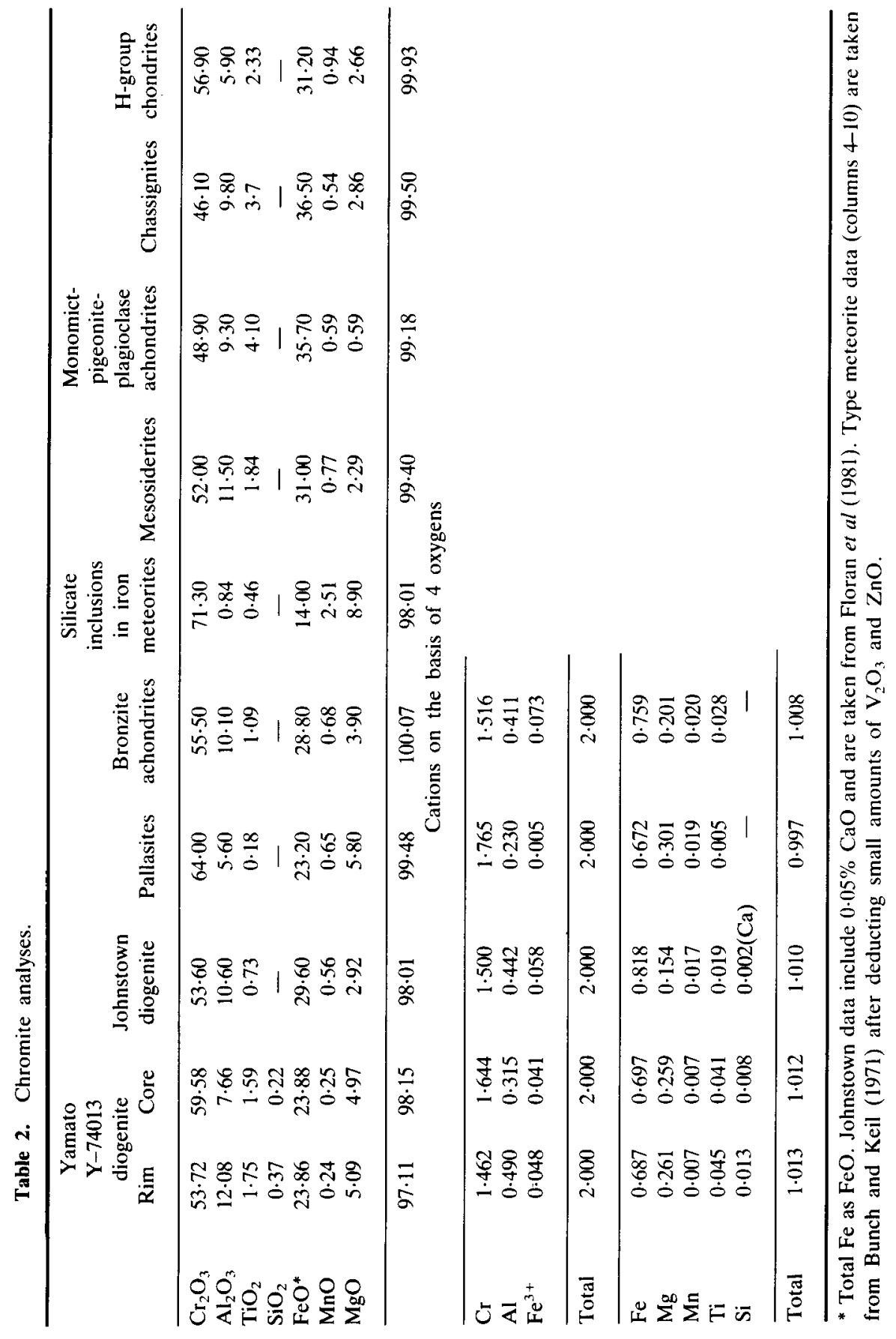


Table 3. Troilite and metal analyses.

\begin{tabular}{lcccccc}
\hline & $\begin{array}{c}\text { Yamato } \\
\text { Y-74013 } \\
\text { diogenite } \\
\text { troilite }\end{array}$ & $\begin{array}{c}\text { Yamato } \\
\text { Y-74013 } \\
\text { diogenite } \\
\text { metal }\end{array}$ & $\begin{array}{c}\text { Element } \\
\text { diogenite } \\
\text { metal } \\
\text { (clast) }\end{array}$ & $\begin{array}{c}\text { Shalka } \\
\text { diogenite } \\
\text { metal } \\
\text { (fine) }\end{array}$ & $\begin{array}{c}\text { Johnstown } \\
\text { diogenite } \\
\text { metal } \\
\text { (clast) }\end{array}$ & $\begin{array}{c}\text { Tatahouine } \\
\text { diogenite } \\
\text { metal } \\
\text { (clast) }\end{array}$ \\
\hline $\mathrm{Fe}$ & 63.65 & 98.59 & 98.87 & 98.87 & 96.19 & 98.49 \\
$\mathrm{Co}$ & 0.07 & 0.85 & 0.11 & 1.66 & 0.71 & 0.75 \\
$\mathrm{Ni}$ & - & 0.56 & 1.02 & 0.07 & 3.10 & 0.76 \\
$\mathrm{~S}$ & 36.64 & - & - & - & - & - \\
\hline & 100.36 & $100 \cdot 00$ & $100 \cdot 00$ & $100 \cdot 00$ & $100 \cdot 00$ & 100.00 \\
\hline
\end{tabular}

* Data taken from Gooley and Moore (1976). The Co and Ni values represent medians of the corresponding ranges.

Table 4. Plagioclase analyses.

\begin{tabular}{|c|c|c|c|}
\hline & \multicolumn{2}{|c|}{$\begin{array}{c}\text { Yamato } \\
\text { Y-74013 diogenite } \\
\text { plagioclase }\end{array}$} & \multirow{2}{*}{$\begin{array}{r}\text { Johnstown } \\
\text { diogenite } \\
\text { plagioclase }\end{array}$} \\
\hline & Centre & $\operatorname{Rim}$ & \\
\hline $\mathrm{SiO}_{2}$ & $48 \cdot 82$ & $48 \cdot 11$ & $46 \cdot 70$ \\
\hline $\mathrm{Al}_{2} \mathrm{O}_{3}$ & $33 \cdot 29$ & $33 \cdot 23$ & $33 \cdot 80$ \\
\hline $\mathrm{FeO}^{*}$ & 0.27 & $0 \cdot 24$ & 0.29 \\
\hline $\mathrm{MgO}$ & $0 \cdot 15$ & $0 \cdot 17$ & 0.46 \\
\hline $\mathrm{CaO}$ & $15 \cdot 93$ & $17 \cdot 28$ & $16 \cdot 90$ \\
\hline $\mathrm{Na}_{2} \mathrm{O}$ & 1.90 & $1 \cdot 44$ & $1 \cdot 39$ \\
\hline $\mathrm{K}_{2} \mathrm{O}$ & $0 \cdot 07$ & $0 \cdot 04$ & 0.07 \\
\hline \multirow[t]{2}{*}{$\mathrm{SrO}$} & - & - & $0 \cdot 05$ \\
\hline & $100 \cdot 43$ & $100 \cdot 51$ & $99 \cdot 66$ \\
\hline \multicolumn{4}{|c|}{ Cations based on 8 oxygens } \\
\hline $\mathrm{Si}$ & $2 \cdot 22$ & $2 \cdot 19$ & $2 \cdot 15$ \\
\hline \multirow[t]{2}{*}{ Al } & $1 \cdot 78$ & $1 \cdot 79$ & $1 \cdot 84$ \\
\hline & $4 \cdot 00$ & 3.98 & 3.99 \\
\hline $\mathrm{Fe}$ & 0.01 & 0.01 & $0 \cdot 01$ \\
\hline $\mathrm{Mg}$ & 0.01 & $0 \cdot 01$ & 0.03 \\
\hline $\mathrm{Ca}$ & 0.78 & 0.84 & 0.84 \\
\hline $\mathrm{Na}$ & $0 \cdot 17$ & $0 \cdot 13$ & $0 \cdot 12$ \\
\hline $\mathrm{K}$ & 0.004 & 0.002 & 0.004 \\
\hline \multirow[t]{2}{*}{$\mathrm{S} r$} & - & - & 0.001 \\
\hline & 0.97 & 0.99 & $1 \cdot 01$ \\
\hline An & $81 \cdot 8$ & $86 \cdot 4$ & $87 \cdot 1$ \\
\hline $\mathrm{Ab}$ & $17 \cdot 8$ & $13 \cdot 4$ & $.12 \cdot 4$ \\
\hline Or & 0.4 & $0 \cdot 2$ & $0 \cdot 4$ \\
\hline
\end{tabular}

* Total Fe as FeO. Johnstown data from Floran et al (1981). 
Table 5. Chromite parameters.

\begin{tabular}{lccccc}
\hline & \multicolumn{2}{c}{$\begin{array}{c}\text { Yamato Y-74013 } \\
\text { diogenite }\end{array}$} & $\begin{array}{c}\text { Johnstown } \\
\text { diogenite }\end{array}$ & $\begin{array}{c}\text { Bronzite } \\
\text { achondrite }\end{array}$ & Pallasite \\
\cline { 2 - 4 } & Rim & Core & 0.188 & 0.265 & 0.448 \\
\hline $\mathrm{Mg} / \mathrm{Fe}^{2+}$ & 0.380 & 0.372 & 0.750 & 0.758 & 0.883 \\
$\mathrm{Y}_{\mathrm{Cr}}^{\mathrm{Sp}}$ & 0.731 & 0.822 & 0.221 & 0.206 & 0.115 \\
$\mathrm{Y}_{\mathrm{Al}}^{\mathrm{Sp}}$ & 0.245 & 0.158 & 0.029 & 0.037 & 0.003 \\
$\mathrm{Y}_{\mathrm{Fe}}^{\mathrm{Sp}}$ & 0.024 & 0.021 & 0.03 & \\
\hline
\end{tabular}

\section{Compositional zoning in chromite}

The chromite of the Yamato diogenite shows compositional zoning (table 2). $\mathrm{Cr}$ decreases from the core to the border significantly. So does Fe, but to a much smaller extent. Al shows a large increase from the core to the rim and $\mathrm{Mg}$ also increases a little from core to rim. Electron microprobe scan shows that all these variations are quite smooth and gradational. $\mathrm{Ti}$ and $\mathrm{Si}$ also show higher values in the rim than in the core.

Two points are of interest here. Compositional variability in the chromite of equilibrated chondrites and achondrites is uncommon (El Gorsey 1976a). Sharp compositional zoning, especially of $\mathrm{Cr}$ and $\mathrm{Al}$ in chromite, of the texturally equilibrated Yamato diogenite is therefore a rather remarkable feature. Secondly, the zoning pattern: decrease in $\mathrm{Cr} /(\mathrm{Cr}+\mathrm{Al}$ ) (from 0.84 to 0.75 ) and $\mathrm{Fe} /$ $(\mathrm{Fe}+\mathrm{Mg}$ ) (from 0.73 to 0.72$)$ and slight increase in $\mathrm{Ti} /(\mathrm{Ti}+\mathrm{Al}+\mathrm{Cr}$ ) (from 0.021 to 0.023 ) from core to rim unmistakably conforms to the zoning trend of the 'early spinel' (El Gorsey 1976b) reported from some relatively coarse-grained lunar basalts. This trend indicates that the chromite grew from a medium, possibly a silicate liquid, which was progressively enriched in $\mathrm{Al}, \mathrm{Mg}$ and $\mathrm{Ti}$. This is possible only if the chromite had crystallized before pyroxene, olivine, plagioclase and any other Ti-rich spinel phase started crystallization.

The pallasitic composition and the zoning pattern of the chromite pose intriguing problems of interpretation, especially in view of the strong indications of textural equilibration of the meteorite. While a compositionally zoned mineral must be out of chemical equilibrium with the coexistent phases, its outermost rim's composition may still be chemically equilibrated. In terrestrial rocks, such cases are quite common. Compositionally zoned garnets frequently have their borders equilibrated with coexistent Fe-Mg silicates e.g. biotite and pyroxenes. In terrestrial silicate-chromite associations also, chromite is quite often zoned, but its rimcomposition is frequently equilibrated with the coexistent, Fe-Mg silicate (Medaris 1975; Wilson 1982; Ozawa 1983; Viswanath 1983). In all such cases, a meaningful quantitative analysis of the P-T conditions of formation is possible on the basis of equilibrium thermodynamic principles. In the following section, we make an attempt of this nature. 


\section{Orthopyroxene-chromite-silica thermobarometry}

For the thermodynamic analysis of an essentially orthopyroxene-chromite rock, $\mathrm{Fe}^{2+}-\mathrm{Mg}$ exchange equilibrium between orthopyroxene and chromite must be the major concern. While there are a fairly large number of geothermometric formulations based on $\mathrm{Fe}^{2+}-\mathrm{Mg}$ exchange between olivine and chromite (Jackson 1969; Evans and Frost 1975; Fabries 1979 etc), there exists no such formulation for an orthopyroxene-chromite association. We therefore developed the general systematics of $\mathrm{Fe}^{2+}-\mathrm{Mg}$ exchange between orthopyroxene and chromite first. The $\mathrm{Mg}-\mathrm{Fe}^{2+}$ exchange reactions in an equilibrated orthopyroxene-chromite assemblage are as follows.

$$
\begin{aligned}
& \mathrm{FeSiO}_{3}+\mathrm{MgCr}_{2} \mathrm{O}_{4}=\mathrm{MgSiO}_{3}+\mathrm{FeCr}_{2} \mathrm{O}_{4}, \\
& \mathrm{FeSiO}_{3}+\mathrm{MgAl}_{2} \mathrm{O}_{4}=\mathrm{MgSiO}_{3}+\mathrm{FeAl}_{2} \mathrm{O}_{4}, \\
& \mathrm{FeSiO}_{3}+\mathrm{MgFe}_{2} \mathrm{O}_{4}=\mathrm{MgSiO}_{3}+\mathrm{Fe}_{3} \mathrm{O}_{4},
\end{aligned}
$$

where $\mathrm{FeSiO}_{3}$ and $\mathrm{MgSiO}_{3}$ represent the ferrosilite and enstatite components of the orthopyroxene and $\mathrm{MgCr}_{2} \mathrm{O}_{4}, \mathrm{MgAl}_{2} \mathrm{O}_{4}, \mathrm{MgFe}_{2} \mathrm{O}_{4}, \mathrm{FeCr}_{2} \mathrm{O}_{4}, \mathrm{FeAl}_{2} \mathrm{O}_{4}$ and $\mathrm{Fe}_{3} \mathrm{O}_{4}$ represent the pirochromite, spinel, magnesioferrite, chromite, hercynite and magnetite components of the chromite. Equations (1), (2) and (3) may be combined to give:

$$
\begin{aligned}
\mathrm{FeSiO}_{3}+ & \mathrm{Y}_{\mathrm{Cr}}^{\mathrm{Sp}} \mathrm{MgCr}_{2} \mathrm{O}_{4}+\mathrm{Y}_{\mathrm{Al}}^{\mathrm{Sp}} \mathrm{MgAl}_{2} \mathrm{O}_{4}+\mathrm{Y}_{\mathrm{Fe}^{3+}}^{\mathrm{Sp}} \mathrm{MgFe}_{2} \mathrm{O}_{4} \\
= & \mathrm{MgSiO}_{3}+\mathrm{Y}_{\mathrm{Cr}}^{\mathrm{Sp}} \mathrm{FeCr}_{2} \mathrm{O}_{4}+\mathrm{Y}_{\mathrm{Al}}^{\mathrm{Sp}} \mathrm{FeAl}_{2} \mathrm{O}_{4} \\
& +\mathrm{Y}_{\mathrm{Fe}^{3+}}^{\mathrm{Sp}} \mathrm{Fe}_{3} \mathrm{O}_{4}
\end{aligned}
$$

where $\quad Y_{\mathrm{Cr}}^{\mathrm{Sp}}=\mathrm{X}_{\mathrm{Cr}}^{\mathrm{Sp}} /\left(\mathrm{X}_{\mathrm{Cr}}^{\mathrm{Sp}}+\mathrm{X}_{\mathrm{Al}}^{\mathrm{Sp}}+\mathrm{X}_{\mathrm{Fe}^{3+}}^{\mathrm{Sp}^{3+}}\right)$

$$
\begin{aligned}
& Y_{\mathrm{Al}}^{\mathrm{Sp}}=X_{\mathrm{Al}}^{\mathrm{Sp}} /\left(X_{\mathrm{Cr}}^{\mathrm{Sp}}+X_{\mathrm{Al}}^{\mathrm{Sp}}+X_{\mathrm{Fe}^{3+}}^{\mathrm{Sp}}\right) \\
& Y_{\mathrm{Fe}^{3+}}^{\mathrm{Sp}}=X_{\mathrm{Fe}^{3+}}^{\mathrm{Sp}} /\left(X_{\mathrm{Cr}}^{\mathrm{Sp}}+X_{\mathrm{Al}}^{\mathrm{Sp}}+X_{\mathrm{Fe}^{3+}}^{\mathrm{Sp}}\right) \\
& Y_{\mathrm{Cr}}^{\mathrm{Sp}}+Y_{\mathrm{Al}}^{\mathrm{Sp}}+Y_{\mathrm{Fe}^{3+}}^{\mathrm{Sp}}=1
\end{aligned}
$$

and $\mathrm{X}_{\mathrm{Cr}}^{\mathrm{Sp}}, \mathrm{X}_{\mathrm{Al}}^{\mathrm{Sp}}$ and $\mathrm{X}_{\mathrm{Fe}^{3+}}^{\mathrm{Sp}}$ represent the mole fractions of $\mathrm{Cr}, \mathrm{Al}$ and $\mathrm{Fe}^{3+}$ in chromite (chrome spinel).

For reaction (4),

$$
K_{4}=\frac{a_{\mathrm{MgSiO}_{3}}^{\mathrm{Opx}} \cdot\left(a_{\mathrm{FeCr}_{2} \mathrm{O}_{4}}^{\mathrm{Sp}}\right)^{\mathrm{YCr}_{\mathrm{Cr}}^{\mathrm{Sp}}} \cdot\left(a_{\mathrm{FeAl}_{2} \mathrm{O}_{4}}^{\mathrm{Sp}}\right)^{\mathrm{Y}_{\mathrm{Al}}^{\mathrm{Sp}}} \cdot\left(a_{\mathrm{Fe}_{3} \mathrm{O}_{4}}^{\mathrm{Sp}}\right)^{\mathrm{Y}_{\mathrm{Fe}}^{3+}}}{a_{\mathrm{FeSiO}_{3}}^{\mathrm{Spx}} \cdot\left(a_{\mathrm{MgCr}_{2} \mathrm{O}_{4}}^{\mathrm{Sp}}\right)^{\mathrm{Y}_{\mathrm{Cr}}^{\mathrm{Sp}}} \cdot\left(a_{\mathrm{MgAl}_{2} \mathrm{O}_{4}}^{\mathrm{Sp}}\right)^{\mathrm{Y}_{\mathrm{Al}}^{\mathrm{Sp}}} \cdot\left(a_{\mathrm{MgFe}_{2} \mathrm{O}_{4}}^{\mathrm{Sp}}\right)^{\mathrm{Y}_{\mathrm{Fe}^{3+}}^{\mathrm{Sp}}}}
$$

where Sp and Opx stand for spinel and orthopyroxene respectively. $K$ and $a$ signify the equilibrium constant and activity respectively.

For equilibrated reactions of the kind (1), (2) and (3), 


$$
\Delta G_{f, P, T}^{\circ}=-\mathrm{RT} \ln K
$$

or

$$
K=\exp \left(-\Delta G_{f . P, T}^{\circ} / \mathrm{RT}\right)
$$

where $\Delta G_{f, P, T}^{\circ}$ represents Gibbs energy (of formation) of the reaction at equilibrium pressure $(P)$ and temperature $(T), R$ is the universal gas constant, and $K$ is the equilibrium constant.

Again, the Gibbs energy of the reactions (1) to (4) are related as follows

$$
\left(\Delta G_{f, P, T}^{\circ}\right)_{4}=\mathrm{Y}_{\mathrm{Cr}}^{\mathrm{Sp}}\left(\Delta G_{f, P . T}^{\circ}\right)_{1}+\mathrm{Y}_{\mathrm{Al}}^{\mathrm{Sp}}\left(\Delta G_{f, P . T}^{\mathrm{o}}\right)_{2}+\mathrm{Y}_{\mathrm{Fe}^{3+}}^{\mathrm{Sp}}\left(\Delta G_{f, P . T}^{\circ}\right)_{3}
$$

where the number in the subscripts refer to the numbers of the reaction equations. Therefore,

$$
\begin{aligned}
K_{4}= & \exp \left[-\left\{\mathrm{Y}_{\mathrm{Cr}}^{\mathrm{Sp}}\left(\Delta G_{f, P, T}^{\circ}\right)_{1}+\mathrm{Y}_{\mathrm{Al}}^{\mathrm{Sp}}\left(\Delta G_{f, P, T}^{\circ}\right)_{2}\right.\right. \\
& \left.\left.+\mathrm{Y}_{\mathrm{Fe}^{3+}}^{\mathrm{Sp}}\left(\Delta G_{f, P, T}^{\circ}\right)_{3}\right\} / \mathrm{RT}\right]
\end{aligned}
$$

Now equating relations (5) and (9), we have the basic activity-free energy relationship between coexisting and equilibrated orthopyroxene and chromite solid solutions:

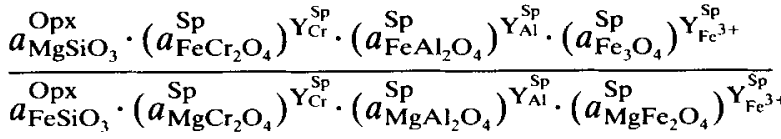

$$
\begin{aligned}
& =\exp \left[-\left\{\mathrm{Y}_{\mathrm{Cr}}^{\mathrm{Sp}}\left(\Delta G_{f, P, T}^{\circ}\right)_{1}+\mathrm{Y}_{\mathrm{Al}}^{\mathrm{Sp}}\left(\Delta G_{f, P, T}^{\circ}\right)_{2}\right.\right. \\
& \left.\left.+\mathrm{Y}_{\mathrm{Fe}^{3+}}^{\mathrm{Sp}}\left(\Delta G_{f . P, T}^{\circ}\right)_{3}\right\} / \mathrm{RT}\right]
\end{aligned}
$$

\subsection{Orthopyroxene-chromite activity-composition relations}

Assuming ideal mixing at each structural site, the activity of orthopyroxene end members may be expressed as follows.

$$
a_{\mathrm{MgSiO}_{3}}^{\mathrm{Opx}}=\mathrm{X}_{\mathrm{MgSiO}_{3}}^{\mathrm{Opx}}=\left(\mathrm{X}_{\mathrm{Mg}, \mathrm{MI}}\right)\left(\mathrm{X}_{\mathrm{Mg}, \mathrm{M} 2}\right)\left(\mathrm{X}_{\mathrm{Si}, \mathrm{T}}\right)^{2}
$$

and

$$
a_{\mathrm{FeSiO}_{3}}^{\mathrm{Opx}}=\mathrm{X}_{\mathrm{FeSiO}_{3}}^{\mathrm{Opx}}=\left(\mathrm{X}_{\mathrm{Fe} . \mathrm{Ml}}\right)\left(\mathrm{X}_{\mathrm{Fc} . \mathrm{M} 2}\right)\left(\mathrm{X}_{\mathrm{Si}, \mathrm{T}}\right)^{2}
$$

where M1, M2 and T stand for M1 and M2 octahedral sites and the tetrahedral site respectively. For chromite the adopted activity-composition relations are as follows.

$$
\begin{aligned}
& a_{\mathrm{MgCr}_{2} \mathrm{O}_{4}}^{\mathrm{Sp}}=\mathrm{X}_{\mathrm{Mg}}^{\mathrm{Sp}} \cdot\left(\mathrm{X}_{\mathrm{Cr}}^{\mathrm{Sp}}\right)^{2}, \\
& a_{\mathrm{FeCr}_{2} \mathrm{O}_{4}}^{\mathrm{Sp}}=X_{\mathrm{Fe}}^{\mathrm{Sp}} \cdot\left(\mathrm{X}_{\mathrm{Cr}}^{\mathrm{Sp}}\right)^{2},
\end{aligned}
$$




$$
\begin{aligned}
& a_{\mathrm{MgAl}_{2} \mathrm{O}_{4}}^{\mathrm{Sp}}=\mathrm{X}_{\mathrm{Mg}}^{\mathrm{Sp}} \cdot\left(\mathrm{X}_{\mathrm{Al}}^{\mathrm{Sp}}\right)^{2}, \\
& a_{\mathrm{Fe} \mathrm{Al}_{2} \mathrm{O}_{4}}^{\mathrm{Sp}}=\mathrm{X}_{\mathrm{Fe}}^{\mathrm{Sp}} \cdot\left(\mathrm{X}_{\mathrm{Al}}^{\mathrm{Sp}}\right)^{2}, \\
& a_{\mathrm{MgFe}_{2} \mathrm{O}_{4}}^{\mathrm{Sp}}=\mathrm{X}_{\mathrm{Mg}}^{\mathrm{Sp}} \cdot\left(\mathrm{X}_{\mathrm{Fe}^{3+}}^{\mathrm{Sp}}\right)^{2}, \\
& a_{\mathrm{Fe}_{3} \mathrm{O}_{4}}^{\mathrm{Sp}}=X_{\mathrm{Fe}}^{\mathrm{Sp}} \cdot\left(X_{\mathrm{Fe}^{3+}}^{\mathrm{Sp}}\right)^{2} .
\end{aligned}
$$

Substituting the activity-composition relations of the orthopyroxene and chromite end members in (10) we get:

$$
\begin{aligned}
& \frac{\left(\mathrm{X}_{\mathrm{Mg}, \mathrm{M} 1}^{\mathrm{Opx}}\right)\left(\mathrm{X}_{\mathrm{Mg}, \mathrm{M} 2}^{\mathrm{Opx}}\right)}{\left(\mathrm{X}_{\mathrm{Fe} . \mathrm{M} 1}^{\mathrm{Opx}}\right)\left(\mathrm{X}_{\mathrm{Fe}, \mathrm{M} 2}^{\mathrm{Opx}}\right)} \cdot \frac{\mathrm{X}_{\mathrm{Fe}{ }^{2+}}^{\mathrm{Sp}}}{\mathrm{X}_{\mathrm{Fe}}^{\mathrm{Sp}}} \\
& =\exp \left[-\left\{\mathrm{Y}_{\mathrm{Cr}}^{\mathrm{Sp}}\left(\Delta G_{f, P, T}^{\circ}\right)_{1}+\mathrm{Y}_{\mathrm{Al}}^{\mathrm{Sp}}\left(\Delta G_{f, P, T}^{\circ}\right)_{2}\right.\right. \\
& \left.\quad+\mathrm{Y}_{\mathrm{Fe}}^{\mathrm{Sp}}\left(\Delta G_{f, P, T}^{\circ}\right)_{3}\right\} / \mathrm{RT}
\end{aligned}
$$

Now expanding the $\Delta G_{f, P, T}^{\circ}$ terms into standard state molar-free energy, entropy and volume of reaction and neglecting the volume terms, because they are exceedingly small for the $\mathrm{Mg}-\mathrm{Fe}^{2+}$ exchange reactions, we get the final equilibrium equation used in the subsequent calculations:

$$
\begin{aligned}
& \frac{\left(\mathrm{X}_{\mathrm{Mg} . \mathrm{M} 1}^{\mathrm{Opx}}\right)\left(\mathrm{X}_{\mathrm{Mg} . \mathrm{M} 2}^{\mathrm{Opx}}\right)}{\left(\mathrm{X}_{\mathrm{Fe}, \mathrm{M} 1}^{\mathrm{Opx}}\right)\left(\mathrm{X}_{\mathrm{Fe}, \mathrm{M} 2}^{\mathrm{Opx}}\right)} \cdot\left(\frac{\mathrm{X}_{\mathrm{Fe}^{2+}}^{\mathrm{Sp}}}{\mathrm{X}_{\mathrm{Mg}}^{\mathrm{Sp}}}\right) \\
& =\exp \left[-\left\{\mathrm{Y}_{\mathrm{Cr}}^{\mathrm{Sp}}\left(\Delta G_{f, 298 \cdot 15,1,1}^{\circ}-\Delta S_{f, 298 \cdot 15,1}^{\circ}(T-298 \cdot 15)\right)\right.\right. \\
& +\mathrm{Y}_{\mathrm{Al}}^{\mathrm{Sp}}\left(\Delta G_{f, 298 \cdot 15,1,2}^{\circ}-\Delta S_{f, 298 \cdot 15,2}^{\circ}(T-298 \cdot 15)\right) \\
& \left.\left.+\mathrm{Y}_{\mathrm{Fe}^{3+}}^{\mathrm{Sp}}\left(\Delta G_{f, 298 \cdot 15,1,3}^{\circ}-\Delta S_{f, 298 \cdot 15,3}^{\circ}(T-298 \cdot 15)\right)\right\} / \mathrm{RT}\right]
\end{aligned}
$$

\subsection{Orthopyroxene-chromite thermometry}

For the validity of a geothermometric reaction, possibly the most important consideration is the sensitivity of the reaction constant $K$ to a temperature change. For common mineralogical reactions of the kind considered here, the sensitivity can be expressed by the equation: $\mathrm{d} \ln K / \mathrm{d} T=\Delta H / \mathrm{RT}^{2}$ where $K, \Delta H, R$ and $T$ stand for reaction constant, heat of reaction, the gas constant and reaction temperature (kelvin) respectively. For many $\mathrm{Fe}^{2+}-\mathrm{Mg}$ exchange reactions in minerals, although $\Delta H$ is not generally as large as in the other kind of thermometric reactions, e.g. a breakdown or net-transfer reaction with low volume change, successful thermometric applications have been made in a wide range of petrological problems. We may cite the examples of biotite and garnet (Ferry and Spear 1978; $|\Delta H|=12454 \mathrm{cal}$ ), garnet and orthopyroxene (Harlay $1984 ;|\Delta H|=$ 
$3740 \pm 610 \mathrm{cal}$ ), olivine and spinel (Jackson 1969; Evans and Frost 1975; $|\Delta H|=6053$ cal (Robie et al 1979). For our proposed orthopyroxene-chromite thermometer, $|\Delta H|$ ranges from 8332 cal to 163956 cal depending on the spinel end-member chosen e.g. with $\mathrm{Cr}, \mathrm{Al}$ or $\mathrm{Fe}^{3+}$ (Robie et al 1979; Helgeson et al 1978; Engi 1978). Thus, from the point of view of temperature sensitivity of the reaction constant, the $\mathrm{Fe}^{2+}-\mathrm{Mg}$ exchange reactions between orthopyroxene and chromite have a considerably better order of validity than most other established $\mathrm{Fe}^{2+}-\mathrm{Mg}$ exchange thermometers and appear to be significantly better suited than olivine-chrome-spinel for the thermometry of ultramafic mineral assemblages.

We now attempt an empirical calibration by applying equation (20) to a number of equilibrated terrestrial orthopyroxene-chromite assemblages. The standard state thermochemical parameters used in these and subsequent calculations are given in table 6. Applying Wood-Banno (1973) orthopyroxene-clinopyroxene thermometer to an orthopyroxene-chromite rock from the Red Mountain ultramafics, New Zealand (Sinton 1977, Sample no. 37010), Sinton (ibid) obtained the equilibration temperature $980^{\circ} \mathrm{C}$. We got $620^{\circ} \mathrm{C}$ for this sample applying equation (20). More recent geothermometric evaluations have shown that Wood-Banno thermometer gives temperatures at least about a $100^{\circ} \mathrm{C}$ too high (Bohlen and Essene 1979). This brings the two temperatures within about $200^{\circ} \mathrm{C}$, putting the uncertainty due to analytical errors at $\pm 50^{\circ} \mathrm{C}$. Mineral thermometers based on cation exchange generally register lower temperature than thermometers based on reconstructing reactions in the same rock, because of the greater kinetic ease of the former during cooling (Newton 1983). We consider it likely that the orthopyroxene-chromite equilibria in Sinton's sample 37010 were quenched at a somewhat lower temperature than the two-pyroxene equilibrium in the same rock. We have made a few more test applications of the orthopyroxene-chromite thermometer to terrestrial ultramafic rocks. These include 5 assemblages from the Seiad Complex of California (Medaris 1975; samples 1-a, 1-b, 2-a, 21-a and 24-c) and 2 assemblages from the Finero Complex of Italy (Medaris ibid, samples 8-a and 8-b). In all these cases, our formulation gives equilibration temperatures reasonably close to independent estimates.

From the foregoing considerations, we take (20) to be a dependable thermometric expression for $\mathrm{Fe}^{2+}-\mathrm{Mg}$ exchange equilibria in coexisting orthopyroxene and

Table 6. Thermochemical data used in the equilibrium calculations.

\begin{tabular}{|c|c|c|c|}
\hline Phase & $\begin{array}{l}\text { Molar volume } \\
\text { cal. bar }{ }^{-1}\end{array}$ & $\begin{array}{l}\text { Gibbs energy of formation } \\
\text { from elements at } 298 \cdot 15^{\circ} \mathrm{K} \\
1 \text { bar Kcal. } \mathrm{mol}^{-1}\end{array}$ & $\begin{array}{l}\text { Entropy of formation } \\
\text { from elements at } 298 \cdot 15^{\circ} \mathrm{K} \text {, } \\
1 \text { bar Gibbs } \mathrm{mol}^{-1}\end{array}$ \\
\hline $\mathrm{FeSiO}_{3}$ & 0.75215 (1) & $-349 \cdot 1594(1)$ & $-69.6355(1)$ \\
\hline $\mathrm{MgSiO}_{3}$ & $0.78757(2)$ & $-267 \cdot 1600(2)$ & $-61.9638(2)$ \\
\hline $\mathrm{MgCr}_{2} \mathrm{O}_{4}$ & $1.05186(1)$ & $-326 \cdot 2001(1)$ & $-80.9847(1)$ \\
\hline $\mathrm{FeCr}_{2} \mathrm{O}_{4}$ & $1.04111(1)$ & $-398.9195(3)$ & $-91.8356(1)$ \\
\hline $\mathrm{MgAl}_{2} \mathrm{O}_{4}$ & 0.94909 (1) & $-519 \cdot 8040(1)$ & $-100 \cdot 1554$ \\
\hline $\mathrm{MgAl}_{2} \mathrm{SiO}_{6}$ & $1 \cdot 39242(4)$ & $-712 \cdot 8553$ & $-142 \cdot 045$ \\
\hline $\mathrm{SiO}_{2}$ (Tridymite) & $0.63410(1)$ & -204.071 & $-43.0292(1)$ \\
\hline
\end{tabular}

Numbers in parentheses give the source of the data: (1) Robie et al (1979) (2) Helgeson et al (1978). 
chromite, which should be good enough for at least a relative and comparative thermometry of meteorites.

Next we apply the orthopyroxene-chromite thermometer to the Johnstown meteorite, a well-studied, equilibrated diogenite (Floran et al 1981). Using our table 6 data and Floran et al's data given in tables 1 and 2, we obtain $1093^{\circ} \mathrm{C}$ as the orthopyroxene-chromite equilibration temperature. This is a probable and realistic near-solidus temperature in an essentially $\mathrm{FeO}-\mathrm{MgO}-\mathrm{Cr}_{2} \mathrm{O}_{3}-\mathrm{SiO}_{2}$ system with small amount of other elements. The same method however gives for Yamato diogenite $1828^{\circ} \mathrm{C}$ (for chromite rim) and $2142^{\circ} \mathrm{C}$ (for chromite cores). Comparison of the Yamato orthopyroxene-chromite compositions with the Johnstown values shows that the single factor responsible for the improbably high Yamato temperature is the high $\mathrm{Mg} / \mathrm{Fe}^{2+}$ ratio of its chromite (table 5). For the Yamato orthopyroxenechromite temperature to be of the same order as that of the Johnstown meteorite, the Yamato chromite's $\mathrm{Mg} / \mathrm{Fe}^{2+}$ value should be $<0 \cdot 20$. This strongly indicates that the large chromite crystals of the Yamato diogenite over the entire grains from core to rim are out of chemical equilibrium with the orthopyroxene. Considered together with the inference from the zoning pattern of the chromite, this suggests that the Yamato chromite has a very high temperature pre-silicate history and for reasons beyond explanation it did not take part effectively in the subsolidus equilibration of the meteorite reflected in its texture.

\subsection{Orthopyroxene-chromite-silica barometry}

Silica is a commonly observed constituent phase in pyroxene achondrite (Gooley et al 1976). We formulate here a new barometer based on the equilibrium:

$$
\underset{\text { in orthopyroxene }}{\mathrm{MgAl}_{2} \mathrm{SiO}_{6}}=\underset{\text { in chromite }}{\mathrm{MgAl}_{2} \mathrm{O}_{4}}+\underset{\text { silica }}{\mathrm{SiO}_{2}}
$$

$\mathrm{MgAl}_{2} \mathrm{SiO}_{6}$ being a hitherto unsynthesized component, its $\Delta G_{f}^{\circ}, \Delta S_{f}^{\circ}$ and $\Delta V^{\circ}$ were calculated from the data of Wood and Banno (1973). All basic thermochemical data used in the calculations are assembled in table 6 . The reaction (4) has a large $\Delta V^{\circ}$ and is an excellent pressure-sensor. The derived barometric expression is:

where

$$
P=\frac{10319.792-0.27635 \mathrm{~T}-\mathrm{RT} \ln \mathrm{K}}{0.208443}
$$

$$
\begin{aligned}
& K=\frac{a_{\mathrm{MgAl}_{2} \mathrm{O}_{4}}^{\mathrm{SP}} \cdot a_{\mathrm{SiO}_{2}}^{\mathrm{Silica}}}{a_{\mathrm{MgAl}_{2} \mathrm{SiO}_{\mathrm{h}}}^{\text {orthopyroxene }}}, \\
& a_{\mathrm{MgAl}_{2} \mathrm{SiO}_{6}}^{\text {orthopyrene }}=4 \cdot \mathrm{X}_{\mathrm{Mg}, \mathrm{M} 2} \cdot \mathrm{X}_{\mathrm{Al}, \mathrm{M} 1} \cdot \mathrm{X}_{\mathrm{Al}, \mathrm{T}} \cdot \mathrm{X}_{\mathrm{Si}, \mathrm{T}} \\
& a_{\mathrm{MgAl}_{2} \mathrm{O}_{4}}^{\mathrm{SP}}=\mathrm{X}_{\mathrm{Mg}}^{\mathrm{Sp}}\left(\mathrm{X}_{\mathrm{Al}}^{\mathrm{Sp}}\right)^{2} .
\end{aligned}
$$

Silica being taken as a pure phase, $a_{\mathrm{SiO}_{2}}$ is equated to 1 . All symbols retain their earlier meaning. 
The equilibrium pressure of Johnstown diogenite, calculated from equation (22) is $21.8 \mathrm{kbar}$ at $1093^{\circ} \mathrm{C}$. For the Yamato diogenite, the same method gives a negative value for the equilibrium pressure. It is obvious that for a realistic pressure value, $a_{\mathrm{MgAl}_{2} \mathrm{O}_{4}}$ must be considerably lower than 0.0064 (the figure we get from the Yamato chromite composition) once again, the $\mathrm{Mg}$ content of the Yamato chromite both at core and rim seems to be disproportionately higher than what its equilibration with the orthopyroxene would require.

\subsection{Orthopyroxene-metal-silica oxygen barometry}

Oxygen fugacity can be determined from the equilibrium:

$$
\begin{aligned}
& 2 \mathrm{Fe} \\
& \text { in metal }
\end{aligned} \underset{\text { silica }}{2 \mathrm{SiO}_{2}}+\mathrm{O}_{2}=\underset{\text { in orthopyroxene }}{2 \mathrm{FeSiO}_{3}}
$$

for which we may write

$$
\log f \mathrm{O}_{2}=\frac{\Delta \mathrm{G}_{\mathrm{f}}^{\circ}}{2 \cdot 3026 \mathrm{RT}}-\frac{\Delta S_{f}^{\circ}(\mathrm{T}-298 \cdot 15)}{2 \cdot 3026 \mathrm{RT}}+\frac{\Delta V(\mathrm{P}-1)}{2 \cdot 3026 \mathrm{RT}}+\log K
$$

For the metal phase we have taken Fe activity to be equal to the mole fraction. Our calculations based on (24), standard state thermochemical data given in table 6 and our mineral composition data for $\mathrm{Y}-74013$ diogenite yield $\log f \mathrm{O}_{2}$ equal to - $20 \cdot 21$ for $880^{\circ} \mathrm{C},-17.72$ for $1000^{\circ} \mathrm{C}$ and -11.08 for $1500^{\circ} \mathrm{C}$. $\log f \mathrm{O}_{2}$ is quite insensitive to pressure. These values are close to those obtained by Gooley et al (1976) for common diogenites i.e. $-17.5 \pm 1.2$ at $880^{\circ} \mathrm{C}$ and -18.5 for the Johnstown diogenite, at the same temperature.

\section{Conclusions}

Texturally Yamato Y-74013 diogenite appears to have attained a high degree of equilibration. Coarse orthopyroxene grains with inclusions of early formed troilite and metal seem to have accumulated in a late $\mathrm{SiO}_{2}$-rich liquid from which a very small amount of plagioclase crystallized last. Orthopyroxene, troilite, metal and plagioclase of the Yamato sample have compositions close to these phases in common orthopyroxenite meteorites. The chromite, however, has significantly higher $\mathrm{Mg} / \mathrm{Fe}^{2+}$ ratio, compared to common diogenites, and its overall pallasitic composition and the zoning pattern point to a high temperature, pre-silicate history. The chromite may represent cognate xenocrysts from an earlier and higher temperature crystallization regime.

For quantitative temperature estimate of orthopyroxene-chromite rocks, a new thermometer has been developed and empirically calibrated by applying it to a number of terrestrial rocks. The thermometer, based on $\mathrm{Mg}-\mathrm{Fe}^{2+}$ exchange reaction between the orthopyroxene and the chrome spinel end members, gives a realistic equilibrium temperature of $1093^{\circ} \mathrm{C}$ for the Johnstown diogenite. A new 
barometer based on Mg-tschermak (in orthopyroxene) - spinel (in chromite) silica equilibrium, yields an equilibrium pressure of $21.8 \mathrm{kbar}$ for the same material at $1093^{\circ} \mathrm{C}$. These values are well in accord with the possible location of diogenites in the deep mentle of a layered eucrite-howardite-diogenite parent planet.

The same P-T sensors, however, give quite improbable pressure and temperature for the Yamato diogenite even when the composition of the outermost rim of the zoned chromite crystals is considered. We conclude that the large chromite grains of the Yamato diogenite crystallized much earlier than the silicates at very high temperatures (possibly higher than $1100^{\circ} \mathrm{C}$ ) and rapidly grew in size with a continuous compositional zoning from core to rim, reflecting a progressive enrichment of the parent liquid in $\mathrm{Mg}, \mathrm{Al}$ and $\mathrm{Ti}$. But for reasons unclear at the moment, these early chromites did not reach chemical equilibrium, even at their outermost rims, with the latter orthopyroxenes displaying an equilibrated, xenomorphic-granular texture. The equilibrium $\log \mathrm{fO}_{2}$ of the Yamato diogenite, calculated from the orthopyroxene - metal - tridymite equilibrium, is between $-20 \cdot 21$ and -11.08 for the temperature range $880-1500^{\circ} \mathrm{C}$. This is a normal oxygen fugacity range for pyroxene achondrites.

\section{Acknowledgements}

We gratefully acknowledge generous financial support received from the Indian Space Research Organisation (ISRO). Dr. Keizo Yanai of the National Institute of Polar Research, Japan kindly provided a bulk sample and one polished thin section of the Yamato Y-74013 diogenite for this work.

\section{References}

Bence A E and Albee A L 1968 J. Geol. 76382

Bohlen S R and Essene E J 1979 Lithos 12335

Bunch T E and Keil K 1971 Am. Mineral. 56146

El Gorsey A 1976a Rev. Mineral. 3 EG47

El Gorsey A 1976b Rev. Mineral. 3 EGl

Evans B W and Frost B R 1975 Geochim. Cosmochim. Acta 39959

Engi M 1978 Ph.D. thesis, Swiss Fed. Inst. Tech. Zurich

Fabries J 1979 Contrib. Mineral. Petrol. 69329

Ferry J M and Spear E S 1978 Contrib. Mineral. Petrol. 66113

Floran R J, Prinz M, Hlava P F, Keil K, Spettel B and Wanke H 1981 Geochim. Cosmochim. Acta 45 2385

Gooley R and Moore C B 1976 Am. Mineral. 61373

Harley S M 1984 Contrib. Mineral. Petrol. 86359

Helgeson H C, Delany J M, Nesbitt H W and Bird D K 1978 Am. J. Sci. 278-A 1

Hirata K and Okumura T 1976 JEOL News 15E 2

Jackson E D 1969 Econ. Geol. Mon. 441

Medaris L G Jr 1975 Geochim. Cosmochim. Acta 39947

Newton R C 1983 Am. J. Sci. 283-A 1

Ozawa K 1983 Contrib. Mineral. Petrol. 8252

Robie R A, Hemingway B S and Fisher J R 1979 US Geol. Surv. Bull. 1452

Sinton J M 1977 J. Petrol. 18216

Takeda H, Miyamoto M, Yanai K and Haramura H 1978 Proc. Second Symp. Antarctic Meteorites 170 Takeda H and Yanai K 1982. Proc. Seventh Symp. Antarctic Meteorites 97 
Viswanath T A 1983 Ph.D. thesis. Ind. Inst. Technology, Kharagpur Wilson A H 1982 J. Petrol. 32 240

Wood B J and Banno S 1973 Contrh. Mineral. Petrol. 42109 